\title{
PROXIMAL BRACHIAL MONOMELIC AMYOTROPHY OR HIRAYAMA DISEASE: NO LONGER AN ALIAS? (case report)
}

\author{
A. Rao \\ RAMAIAH MEDICAL COLLEGE, BANGALORE, KARNATAKA, INDIA
}

Background. Brachial Monomelic Amyotrophy (BMMA) has been called as Hirayama disease (HD) when it is characterized by unilateral distal upper limb weakness and atrophy that shows progression for a limited period and is associated with typical features on MRI of cervical spine in flexion.

Objective was to explore the differences when BMMA affects the proximal upper limb muscles with the help of case report.

Methods. A case report of BMMA in an adult Indian male is represented.

Results. A 30-year-old man presented to us with a history of weakness in the proximal aspect of his left upper limb that began four years ago. The weakness was progressive up until 6 months prior to his presentation since when the weakness had neither worsened nor improved. Cervical spine contrast enhanced MRI revealed mild loss of cervical lordosis, but no features of HD like localized cord atrophy, loss of attachment of dura from subjacent lamina on neutral position axial T2WI MRI, nor any presence of posterior epidural crescentic enhancing mass on flexion contrast sagittal T1WI MRI. The patient was managed with supportive therapy and has been under regular follow up ever since. His clinical status has been stable.

Conclusions. We support the suggestion to consider proximal Brachial Monomelic Amyotrophy to be a separate entity and to be distinguished from Hirayama disease that should be reserved for patients with distal upper limb involvement with cervical MRI findings on flexion studies.

KEY WORDS: Brachial Monomelic Amyotrophy; Hirayama disease; cervical spine flexion MRI.

\section{Introduction}

Traditionally Hirayama disease (HD), also known as Brachial Monomelic Amyotrophy (BMMA), has been described as a condition characterized by insidious onset unilateral upper limb weakness and wasting [1]. HD is considered to be a focal degenerative motor neuron disease (MND) affecting the cervical spinal cord. Though it is considered as a variant of motor neuron disease, it differs from other forms of MND, since it clinically involves only one limb and, after a brief period of progression, the neurological deficit becomes static [2].

Recently there have been arguments to recognize $\mathrm{HD}$ and BMMA as separate diseases with different clinical and neuroimaging features and therefore possibly different etiopathologies. Hassan K.M. et al. suggested that "Hirayama disease" should be used for cases with clinically unilateral upper limb distal muscle weakness and atrophy with cervical spine magnetic resonance imaging (MRI) demonstrating and the typical findings

Corresponding author: Akshay Rao, assistant professor, department of General Medicine, Ramaiah Medical College, Bangalore, Karnataka, India.

E-mail:akshayrao19@yahoo.com highlighted below, restricting the term "brachial monomelic amyotrophy" for cases of proximal upper limb atrophy without typical MRI features of HD [3].

Typical MRI findings in the cervical spine in Hirayama disease include [3]:

In Neutral position

- Abnormal cervical curvature (loss of cervical lordosis).

- Localized lower cervical cord atrophy with asymmetric cord flattening.

- Intramedullary hyperintensity in lower cervical cord.

Flexion position

- Loss of attachment between posterior dural sac and subjacent lamina.

- Anterior shifting of posterior cervical dural wall on flexion with Prominent epidural flow voids.

- Enhancing epidural mass in lower cervical region.

So, we report a case with isolated weakness and atrophy of proximal left upper limb muscles, without the typical MRI findings of HD.

\section{Case study}

A 30-year-old man, who was a farmer by occupation, presented to us in July 2015, with 
history of weakness in the proximal aspect of his left upper limb that began four years ago. The weakness was progressive up until 6 months prior to his presentation since when the weakness had neither worsened nor improved. There was no trauma or fever preceding the onset of weakness, no family history of similar complaints nor any exposure to toxins or heavy metals. He denied pain, numbness, diplopia, dysphagia, ptosis, muscle cramps, fasciculations, and headache or neck pain. Examination revealed marked atrophy and weakness in the proximal aspect of his left upper limb (Fig. 1).

Fasciculations were noted in the left deltoid. The left biceps and supinator reflexes were diminished. The rest of the motor system examination was unremarkable. Sensory and cranial nerve examinations were normal.

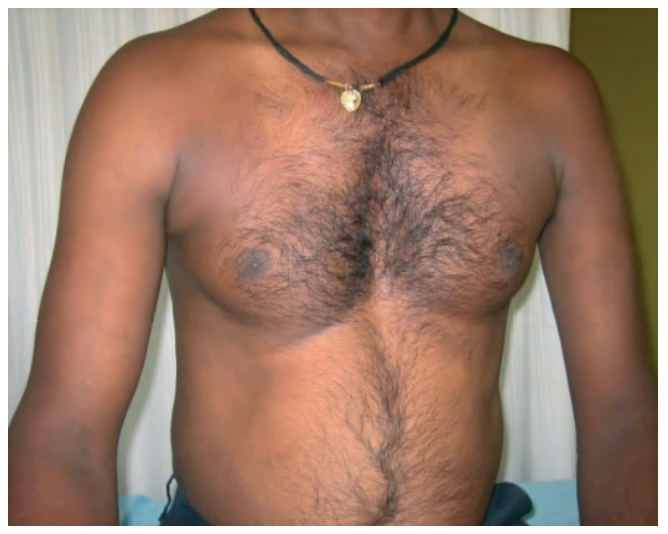

Electroneuromyography (ENMG) showed denervation pattern with reduced motor action potentials and fasciculations in the left deltoid (Fig. 2).

Motor nerve conduction study showed reduced Compound Motor Action Potentials (CMAP) amplitudes in left axillary, musculocutaneous and infraspinatus, but the sensory nerve conduction was normal. Cervical spine contrast enhanced MRI revealed mild loss of cervical lordosis, but no features of HD like localized cord atrophy, loss of attachment of dura from subjacent lamina on neutral position axial T2WI MRI, nor any presence of posterior epidural crescentic enhancing mass on flexion contrast sagittal T1WI MRI (Fig. 3). The patient was managed with supportive therapy and has been under regular follow up ever since. His clinical status has been stable.

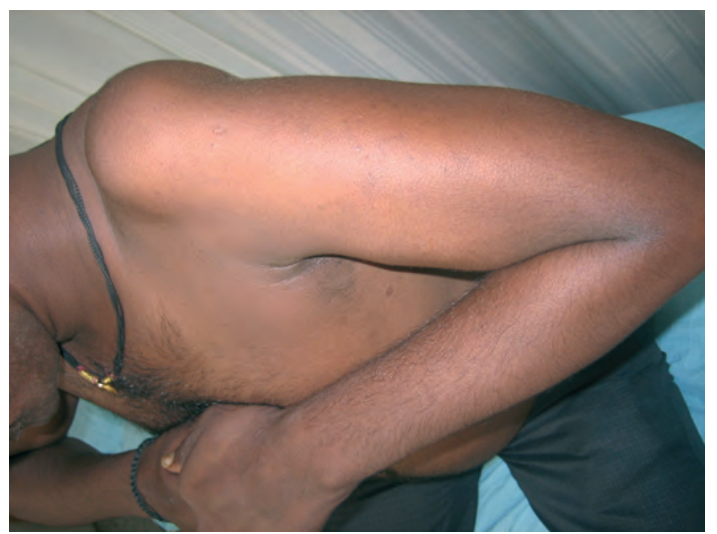

Fig. 1. Photographs displaying atrophy of the proximal aspect of the left upper limb with loss of contour of the left shoulder.
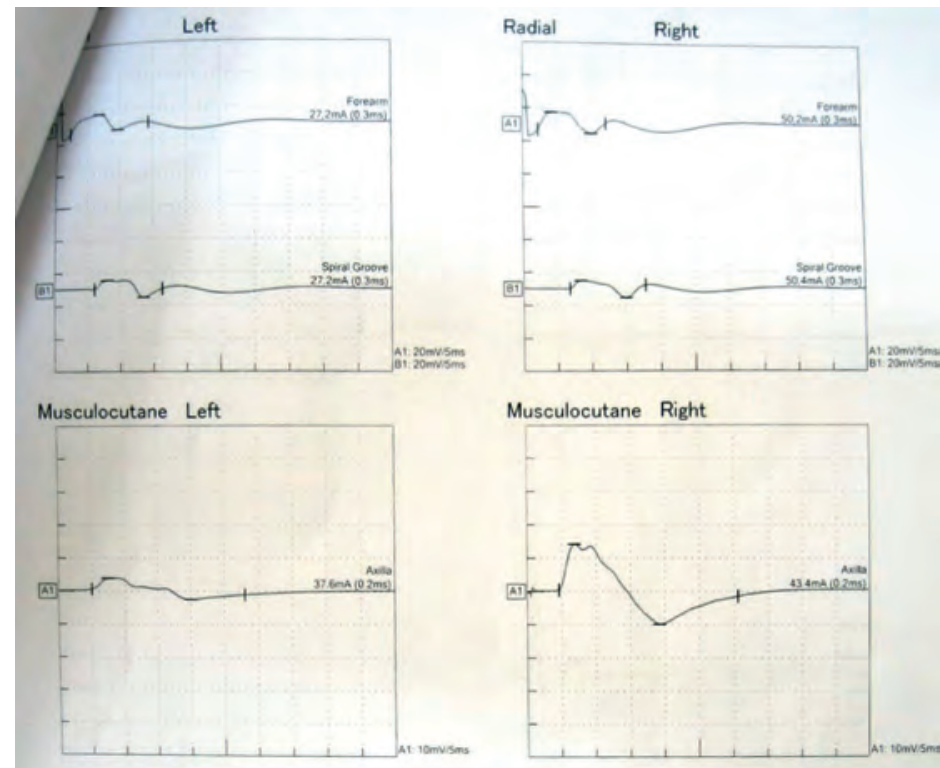

Fig. 2. Electroneurogram comparison of the nerves supplying upper limb muscles revealed reduced Compound Motor Action Potential (CMAP) on the left musculocutaneous nerve. 

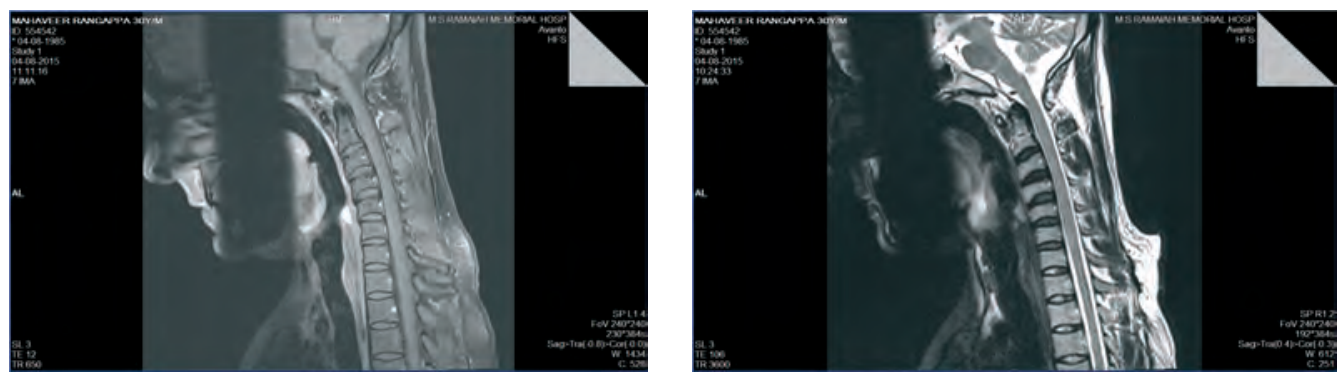

Fig. 3. MRI studies of the cervical spine in flexion failed to demonstrate the typical changes associated with Hirayama disease.

\section{Discussion}

Hirayama disease is a sporadic disease characterized by wasting and weakness confined to only one upper limb, initially progressing for 2-4 years which is followed by a stationary course, without clinical involvement of other limbs. There is no cranial nerve, cerebral, pyramidal tract or sensory involvement. In upper limb involvement, atrophy of the medial forearm muscles and the small muscles of hand are common [4]. EMG is characterized by fibrillations, positive sharp waves, and fasciculations consistent with the underlying pathophysiologic process of denervation [5]. MRI abnormalities in HD have been consistently reported in studies by Hassan et al., Sonwalkar et al. and Raval et al. [3, 6, 7].

The debate continues whether HD represents a focal primary lower MND or a local consequence of anatomical variation in the cervical spine [8]. It has been suggested that an imbalanced growth causes disproportional length between the patient's vertebral column and spinal canal contents, leading to tightening of dural sac and anterior displacement of posterior dural wall on neck flexion [9], thereby compressing the cord against the posterior margin of adjacent vertebrae producing microcirculatory disturbances in the lower cervical cord resulting in necrosis of anterior horn cells, gliosis and localized lower cervical cord atrophy, consistent with pathologic findings on autopsy [10].

As with any case presenting with unilateral upper limb weakness and atrophy, there are other differential diagnoses to be considered for this patient $[11,12]$ :

Multifocal motor neuropathy with conduction blocks involves upper limbs in asymmetrical manner with predominant distal muscle involvement, atrophy isn't a prominent feature and ENMG shows demyelination with conduction blocks and has high serum titers of anti-GM1 ganglioside antibodies.
In Spinal Muscular Atrophy and motor neuropathy, such as that due to lead toxicity, upper limbs involvement is bilateral and symmetric.

A chronic focal myositis can be differentiated by an elevated serum creatine phosphokinase, and the EMG, and the muscle histologic features.

Neuralgic amyotrophy or brachial neuritis is present with characteristic deep shoulder aching dysesthesia. There is good prognosis for full recovery.

An entity called "late-progression of poliomyelitis" merits a comment. In this disease there are: 1) a definite history of poliomyelitis; 2) residual but stable neurologic deficits; 3 ) a quiescent period of ten years or more. Our patient did not have any history of poliomyelitis in his past.

Cases of proximal brachial MMA reported in the literature are very limited, and no such cases have been shown to have dynamic compression of cervical cord on MRI. In 2000, De Freitas M.R.G. et al. published a case series of brachial MMA patients including one patient with proximal disease, in whom cervical MRI was normal [11]. In 2008, Orsini M. et al. reported two young men with proximal right upper limb MMA, and both had a normal cervical MRI [12]. In 2013, Hassan K.M. et al. also described two young males with proximal left upper limb MMA with only mild loss of cervical lordosis on MRI [3]. In 2015, Yoo S.D. et al. reported a patient with proximal upper limb atrophy with flexion cervical MRI showing typical features of HD, but this patient had certain atypical features such as left deltoid tenderness and upper motor neuron signs in ipsilateral upper and lower limbs [13]. In 2017, Aundhakar S.C. et al. reported a case of right upper limb wasting and weakness with typical MRI findings of HD but were involved of proximal as well as distal upper limb muscles [14]. 
Hence, it appears that proximal brachial BMMA may thus have a pathogenesis different from the dynamic ischemia of lower cervical cord postulated for distal upper limb wasting of HD. Perhaps such patients need not be subjected to cervical spine flexion contrast MRI; an MRI of the cervical spine in neutral position may suffice to exclude compressive myelopathy due to other causes.

\section{Conclusions}

We support the suggestion of Hassan et al. to consider proximal Brachial Monomelic
Amyotrophy to be a separate entity and to be distinguished from Hirayama disease that should be reserved for patients with distal upper limb involvement with cervical MRI findings on flexion studies. Thus, there is a need to explore a different pathological mechanism for Brachial Monomelic Amyotrophy. We also suggest that performing flexion contrast MRI of the cervical spine is not necessary in proximal Brachial Monomelic Amyotrophy patients.

\section{Conflict of interest}

The author declares no conflict of interest.

\section{ПРОКСИМАЛЬНА ПЛЕЧОВА МОНОМЕЛІЧНА АМІОТРОФІЯ АБО ХВОРОБА ХІРАЯМА: БІЛЬШЕ НЕ ОДНЕ I ТЕ Ж? (КЛІНІЧНИЙ ВИПАДОК)}

A. Rao

RAMAIAH MEDICAL COLLEGE, BANGALORE, KARNATAKA, INDIA

Вступ. Брахіальну мономелічну аміотрофію (БММА) ще називають хворобою Хіраяма, якщо вона характеризується однобічною дистальною слабкістю верхньої кінцівки і атрофією, яка прогресує протягом невеликого періоду часу, а МРТ виявляє типові ознаки у шийному відділі хребта у положенні його згинання.

Мета роботи дослідити особливості та відмінності перебігу хвороби при ізольованому ураженні проксимального відділу верхньої кінцівки на прикладі клінічного випадку.

Методи. Описано та проаналізовано клінічний випадок брахіальної мономелічної аміоатрофії у дорослого чоловіка, жителя Індії.

Результати. 30-річний чоловік звернувся зі скаргами на слабкість у проксимальному відділі лівої верхньої кінцівки, яка триває близько чотирьох років. Слабкість прогресувала приблизно півроку після ії появи, з того часу - без змін, не спостерігалося ні погіршення ні покращення стану руки. МРТ шийного відділу з контрастом виявила невелике сплощення шийного лордозу, однак не було виявлено типових ознак хвороби Хіраяма: локалізованої вогнищевої атрофії спинного мозку, відшарування задньої стінки дурального мішка від стінок хребцевого каналу в нейтральному положенні на сагітальних Т2ВI зображеннях, чи наявність додаткових мас-утворів на задній поверхні твердої мозкової оболонки на сагітальних Т2ВІ зображеннях МРТ при згинанні шийного відділу хребта. Пацієнтові було призначено підтримуючу терапію, він знаходиться під регулярним спостереженням лікаря. Клінічний стан стабільний.

Висновки. На основі аналізу клінічного випадку, ми підтримуємо пропозицію розглядати брахіальну мономелічну атрофію як окрему нозологічну одиницю, відмінну від хвороби Хіраяма, у пацієнтів 3 ураженням верхньої кінцівки на підставі результатів обстеження МРТ шийного відділу хребта у положенні згинання.

КЛЮЧОВІ СЛОВА: Брахіальна мономелічна аміотрофія; хвороба Хіраяма; МРТ шийного відділу хребта у положенні згинання.

\section{Information about the author}

Akshay Rao - assistant professor, department of General Medicine, Ramaiah Medical

College, MSRIT post, MSR nagar, Mathikere, Bangalore, Karnataka, India, PIN 560054

ORCID 0000-0002-4111-5424, e-mail: akshayrao19@yahoo.com 


\section{References}

1. Hirayama K, Toyukura Y, Tsubaki T. Juvenile muscular atrophy of unilateral upper extremity: A new clinical entity. Psychiatr Neurol Jpn.1959;61:2190-7

2. Uncini A, Servidei S, Delli Pizzi C, Cutarella R, Di Muzio A, Gambi D, et al. Benign monomelic amyotrophy of lower limb: report of three cases. Acta Neurol Scand. 1992;85:397-400.

doi: 10.1111/j.1600-0404.1992.tb06035.x

3. Hassan KM, Sahni H. Nosology of juvenile muscular atrophy of distal upper extremity: from monomelic amyotrophy to Hirayama disease--Indian perspective Nosology of juvenile muscular atrophy of distal upper extremity: from monomelic amyotrophy to Hirayama disease - Indian perspective. Biomed Res Int. 2013;2013:478516.

doi: $10.1155 / 2013 / 478516$

4. Gourie-Devi M, Suresh T.,Shankar S. Monomelic Amyotrophy. Arch Neurol. 1984; 41:388-394.

doi: 10.1001/archneur.1984. 04050160050015

5. De Frietas Marcos R. G., Nascimento Osvaldo J.M., Benign Monomelic Amyotrophy: A study of 21 cases. Arq Neuropsiquiatr.2000; 58(3-B):808-813. https://pdfs.semanticscholar.org/4da3/405f8bf181 55c0b988f1dea56d2fe26d8b8e.pdf

6. Sonwalkar HA, Shah RS, Khan FK, Gupta AK Bodhey NK, Vottath S, et al. Imaging features in Hirayama disease. Neurol India 2008;56:22-6.

doi: 10.4103/0028-3886.39307

7. Raval M, Kumari R, Dung AA, Guglani B, Gupta N, Gupta R. MRI findings in Hirayama disease. Indian J Radiol Imaging. 2010;20(4):245-9. doi: $10.4103 / 0971-3026.73528$
8. Turner MR, Talbot K Mimics and chameleons in motor neurone disease. Practical Neurology. 2013;13:153-164.

doi: 10.1136/practneurol-2013- 000557

9. Hirayama K. Juvenile muscular atrophy of distal upper extremity (Hirayama disease). Intern Med. 2000;39:283-90.

doi: 10.2169/internalmedicine.39.283

10. Hirayama K., Tomonaga M., Kitano K., Yamada T., Kojima S., Arai K. The first autopsy case of 'juvenile muscular atrophy of unilateral upper extremity'. Shinkei Naika. 1985;22(2):85-86.

11. De Freitas MRG, Nascimento OJM. Benign monomelic amyotrophy- A study of twenty-one cases. Arq neuropsiquiatr. 2000;58(3-b):808-813.

doi: 10.1590/S0004-282X2000000500003

12. Orsini M, Freitas MRG, Catharino A, Mello MP, Nascimento OJM. Upper Limb Proximal Form of Benign Monomelic Amyotrophy: on Purpose of 2 Cases. Rev Bras Neurol.2008; 44 (3): 13-17.

https://pdfs.semanticscholar.org/4da3/405f8bf 18155c0b988f1dea56d2fe26d8b8e.pdf

13. Yoo SD, Kim HS, Yun D H, Kim DH, Chon J, Lee SA, et al. Monomelic amyotrophy (hirayama disease) with upper motor neuron signs: a case report. Ann Rehabil Med. 2015; 39(1):122-7.

doi: 10.5535/arm.2015.39.1.122

14. Aundhakar SC, Mahajan SK, Chhapra DA. Hirayama's Disease: A Rare Clinical Variant of Amyotrophic Lateral Sclerosis. Adv Biomed Res. 2017;6:95. Published 2017 Jul 28.

doi: 10.4103/2277-9175.211797.

Received 16 February 2019; revised 20 February 2019; accepted 18 March 2019.

This is an open access article distributed under the Creative Commons Attribution License, which permits unrestricted use, distribution, and reproduction in any medium, provided the original work is properly cited. 